\title{
EFFECT OF ALKANE SULPHONIC ESTERS ON OVARIAN DEVELOPMENT AND FUNCTION IN THE RAT
}

\author{
B. N. HEMSWORTH* \\ Paterson Laboratories, Christie Hospital and Holt Radium Institute, Manchester
}

(Received 23rd Fanuary 1968)

\begin{abstract}
Summary. Closely related members of a homologous series of alkane sulphonic esters were administered to pregnant rats and their effect on oogenesis and fertility of female offspring studied. A marked antifertility action due to the diesters $\mathrm{n}=1,3,4$ and the branched chain monoester isopropyl methanesulphonate was referable to interference with oogonia. Methyl and ethyl monoesters also had an antifertility action although their effect was less evident.
\end{abstract}

\section{INTRODUCTION}

Bollag (1954) reported that busulphan (2 mg/animal) given to pregnant rats 5 to 7 days before parturition caused sterility in male and female offspring. Galton \& Till (1956) stated that "earlier in pregnancy quite large doses do not interfere with its course and the $F_{1}$ and $F_{2}$ generations were apparently healthy".

After implantation of the rat embryo, susceptibility of the primordial germ cells to busulphan $(10 \mathrm{mg} / \mathrm{kg})$ increased, and treatment from the 13th day of gestation and later caused the destruction of gonocytes (Hemsworth \& Jackson, 1963a) and oogonia (Hemsworth \& Jackson, 1963b). In the foetal ovary, oogonia enter meiotic prophase after Day 15 post coitum and oocytes are less susceptible to the destructive action of busulphan. Susceptibility of oogonia and gonocytes resembles that of spermatogonia in adult rats (Jackson, Fox \& Craig, 1961); similarly, diminished sensitivity of oocytes recalls the resistance of spermatocytes to this compound.

The purpose of this study was to investigate the relationship between structure and biological activity of closely related alkane sulphonic esters.

\section{MATERIALS AND METHODS}

\section{Animals}

Wistar rats of American origin were fed on a diet supplied by the Scottish North Eastern Agricultural Society. Females were placed separately in boxes, paired with fertile males and the day spermatozoa were found in the vaginal smear was regarded as Day 0 of pregnancy. Males were removed and dams allowed to go to term.

* Present address: Huntingdon Research Centre, Huntingdon. 


\section{Treatment}

At least four dams were dosed by the intra-peritoneal route (i.p.) on each selected day during pregnancy and were allowed to go to term. Offspring from three litters were killed by ether vapour on Days 1 and 15 post partum and their ovaries fixed for examination of their histology. Remaining offspring were kept to maturity, when their fertility was assessed. They were killed by ether vapour when 6 months or a year old and their ovaries prepared for examination of their histology.

\section{Histological techniques}

Ovaries were fixed in formol saline, embedded in paraffin wax and 7- $\mu$ sections cut from the mid-region of each organ. In certain cases entire organs were serially sectioned. Sections were stained in haematoxylin and mounted in Xam.

\section{Fertility studies}

Females were paired with proven fertile males until insemination occurred. Those which failed to mate when left with males for at least 2 weeks were regarded as sterile.

\section{RESULTS}

\section{Effect of alkane sulphonates during pregnancy on the ovarian histology of offspring}

Monoesters. A near-lethal dose of methyl methanesulphonate $(100 \mathrm{mg} / \mathrm{kg})$ or ethyl methanesulphonate $(200 \mathrm{mg} / \mathrm{kg})$ was administered on the 15 th day of pregnancy. Ovaries from 1-day-, 15-day- and 6-month-old offspring appeared normal, but by the time offspring were a year old their ovaries were virtually devoid of germ cells. Isopropyl methanesulphonate $(50 \mathrm{mg} / \mathrm{kg})$ had a powerful destructive action on oogonia and administration on the 16th day of pregnancy resulted in elimination of germ cells from offspring. When dams were treated later (Day 20) ovaries from offspring appeared normal (Pl. 1, Figs. 1 to 6).

$$
\begin{array}{ll}
\multicolumn{1}{c}{\text { EXPLANATION }} & \text { OF PLATE 1 } \\
\mathrm{CL}=\text { Corpus luteum } & \mathbf{G}=\text { Germinal epithelium } \\
\mathrm{GF}=\text { Graafian follicle } & \mathrm{OG}=\text { Oocyte } \\
\mathrm{PF}=\text { Primordial follicle } & \mathrm{ST}=\text { Ovarian stroma }
\end{array}
$$

Figs. 1 to 6 show the effect of i.p. injections of isopropyl methanesulphonate IMS ( $50 \mathrm{mg} /$ $\mathrm{kg}$ ) into pregnant rats on the 16th or 20th day of gestation on female foetuses allowed to go to term.

Fig. 1. An ovary, 1 day post partum showing the effect of treatment on the 16 th day of gestation. Oocytes absent.

Fig. 2. An ovary, 1 day post partum. Dams treated on the 20th day of gestation. Numerous oocytes present in meiotic prophase or dictyate condition.

FIG. 3. An ovary, 15 days post partum showing the effect of treatment on the 16 th day of gestation. Oocytes not seen.

Fig. 4. An ovary, 15 days post partum showing the effect of treatment on the 20th day of gestation. Oocytes, primordial follicles and more advanced stages of follicular development present.

Fig. 5. An ovary, 6 months post partum showing the effect of treatment on the 16 th day of pregnancy. Oocytes and Graafian follicles absent.

Fig. 6. An ovary, 6 months past partum showing the effect of treatment on the 20th day of pregnancy. Graafian follicles and corpora lutea present. 


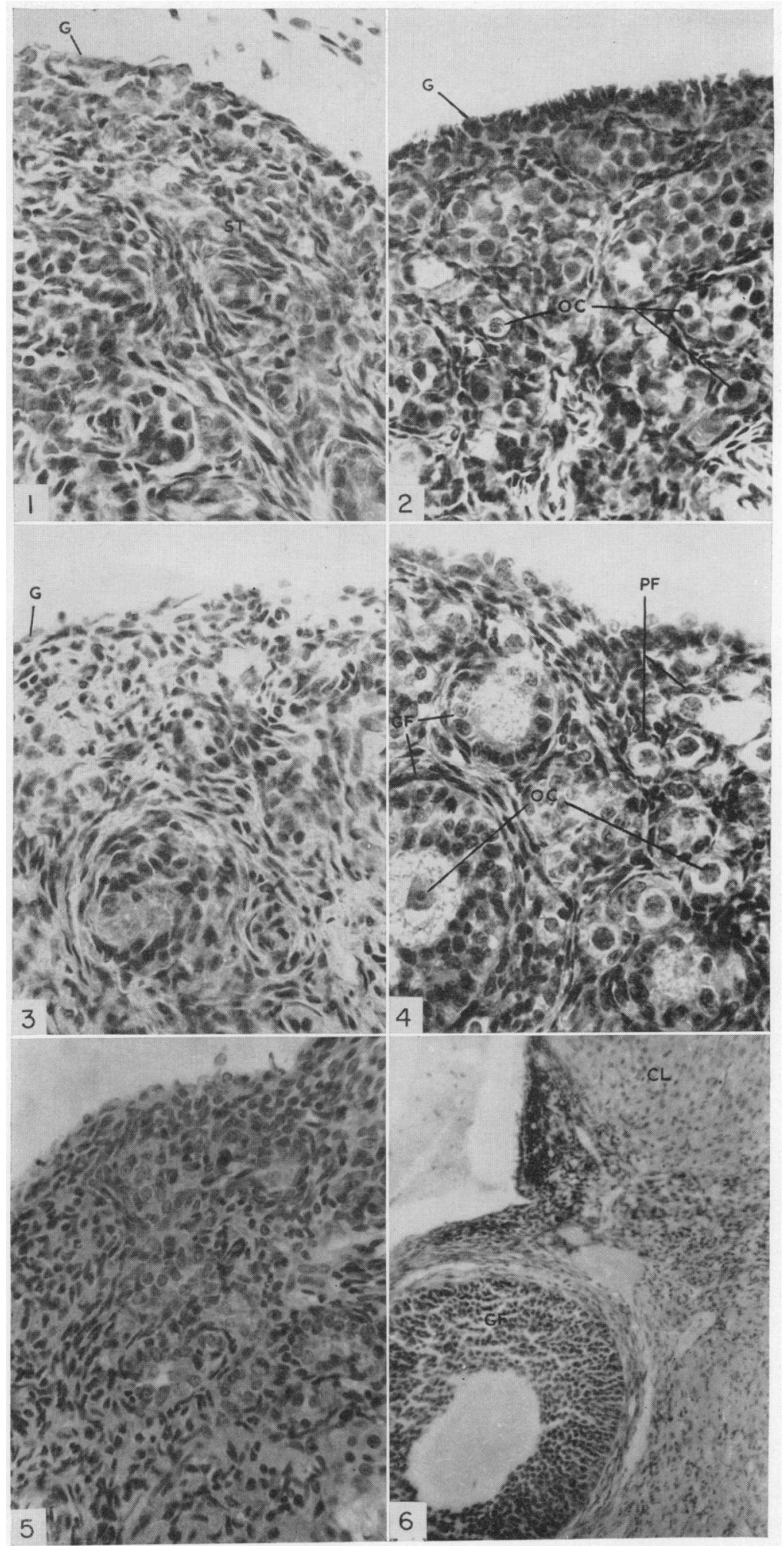


Diesters. Methylene dimethanesulphonate $(\mathrm{n}=1 ; 15 \mathrm{mg} / \mathrm{kg})$ or trimethylene dimethanesulphonate $(\mathrm{n}=3 ; 50 \mathrm{mg} / \mathrm{kg})$ was administered to dams on the 15 th day of pregnancy. Although a few oocytes were seen in ovaries from 1-day-old offspring, by 15 days post partum surviving germ cells were associated with advanced stages of follicular development and primordial follicles were virtually absent. Oocytes were not seen in serial sections prepared from ovaries of 6month-old offspring. A near lethal dose of dimethylene dimethanesulphonate $(\mathrm{n}=2 ; 100 \mathrm{mg} / \mathrm{kg})$ was administered on the 15 th day of pregnancy, the ovarian histology of 1-day-, 15-day- and 6-month-old offspring appeared normal.

TABLE 1

STERILE OFFSPRING

\begin{tabular}{|c|c|c|c|c|c|c|}
\hline & \multirow{2}{*}{$\begin{array}{c}\text { Dose } \\
(m g / k g \text { i.p. })\end{array}$} & \multicolumn{5}{|c|}{$\begin{array}{c}\text { Day of pregnancy when dams were } \\
\text { treated }\end{array}$} \\
\hline & & 13 & 14 & 15 & 16 & 20 \\
\hline $\begin{array}{l}\text { MONOESTERS } \\
\text { Isopropyl } \\
\text { methanesulphonate } \\
\text { Methyl } \\
\text { methanesulphonate } \\
\text { Methyl } \\
\text { methanesulphonate } \\
\text { (1-year-old offspring) } \\
\text { Ethyl methanesulphonate } \\
\text { Ethyl methanesulphonate } \\
\text { (1-year-old offspring) }\end{array}$ & $\begin{array}{r}50 \\
100 \\
100 \\
200 \\
200\end{array}$ & $\begin{array}{l}- \\
-\end{array}$ & $\begin{array}{c}6 / 6 \\
-\end{array}$ & $\begin{array}{l}4 / 6 \\
0 / 5\end{array}$ & $\begin{array}{l}5 / 6 \\
1 / 6 \\
6 / 6 \\
0 / 6 \\
-\end{array}$ & $\begin{array}{l}0 / 5 \\
-\end{array}$ \\
\hline $\begin{array}{l}\text { DIESTERS } \\
\mathrm{CH}_{3} \mathrm{SO}_{2} \mathrm{O} \backslash\left(\mathrm{CH}_{3}\right)_{\mathrm{a}} \\
\begin{array}{l}\mathrm{CH}_{3} \mathrm{SO}_{2} \mathrm{O} \\
\mathrm{n}=1 \\
\mathrm{n}=2 \\
\mathrm{n}=3 \\
\mathrm{n}=4\end{array}\end{array}$ & $\begin{array}{r}15 \\
100 \\
50 \\
10\end{array}$ & $\begin{array}{l}\overline{0 / 6} \\
4 / 5 \\
6 / 6\end{array}$ & $\begin{array}{l}\overline{1 / 6} \\
3 / 3 \\
6 / 6\end{array}$ & $\begin{array}{l}6 / 6 \\
0 / 6 \\
6 / 6 \\
6 / 6\end{array}$ & $\frac{\bar{Z}}{3 / 6}$ & $\begin{array}{l}1 / 6 \\
0 / 6 \\
1 / 6 \\
0 / 6\end{array}$ \\
\hline
\end{tabular}

Drugs were injected into the peritoneal cavity of pregnant rats on a selected day during gestation. The monoesters of methanesulphonic acid were administered in normal saline. The diesters $n=1$ to 3 were dissolved in a solution of dimethyl sulphoxide and normal saline. Busulphan $(n=4)$ was suspended in arachis oil. Dams were allowed to go to term and fertility of offspring was assessed when they were at least 4 months old. Numerator in each fraction shows number of rats sterile, denominator indicates number of rats tested.

\section{Effect of alkane sulphonates during pregnancy on the fertility of offspring}

Methyl and ethyl monoesters were administered to dams on the 15th or 16th day of pregnancy and although offspring were fertile, by the time they were a year old most had become sterile (Table 1). Isopropyl methanesulphonate ( $50 \mathrm{mg} / \mathrm{kg}$ ) from Days 13 to 16 post coitum inclusive caused sterility, but when dams were treated later (Day 20) offspring were fertile.

Diesters $\mathrm{n}=1,3$ and 4 between Days 13 and 15 post coitum inclusive caused sterility, but when dams were treated on the 20th day of gestation offspring were fertile. Methylene dimethanesulphonate $(\mathrm{n}=2 ; 100 \mathrm{mg} / \mathrm{kg})$ was administered between Days 13 and 20 post coitum inclusive; offspring were fertile. 
Normal saline, in which the monoesters were dissolved and dimethyl sulphoxide used to dissolve the diesters $\mathrm{n}=1$ to 3 , was injected into dams on the 15th day of pregnancy; offspring were fertile.

\section{Effect of alkane sulphonates on weight of body and selected organs from offspring}

The monesters had little effect on body weight unlike the diesters $n=1$ to 4; however, attention must be drawn to the finding that dimethyl sulphoxide, in which the diesters $n=1$ to 3 were dissolved, and arachis oil in which busulphan $(\mathrm{n}=4)$ was suspended caused a $9 \%$ decrease in body weight (Table 2$)$.

TABLE 2

PERGENTAGE REDUCTION IN WEIGHT OF BODY, OVARIES AND AGGESSORY SEX ORGANS OF 6-MONTH-OLD OFFSPRING

\begin{tabular}{|c|c|c|c|c|}
\hline & $\begin{array}{c}\text { Dose } \\
\text { (mg/kg i.p.) }\end{array}$ & Body & Ovaries & $\begin{array}{c}\text { Genital } \\
\text { tract }\end{array}$ \\
\hline $\begin{array}{l}\text { MONOESTERs } \\
\text { Isopropyl methanesulphonate } \\
\text { Methyl methanesulphonate } \\
\text { Ethyl methanesulphonate }\end{array}$ & $\begin{array}{r}50 \\
100 \\
200\end{array}$ & $\begin{array}{l}2 \\
1 \\
0\end{array}$ & $\begin{array}{r}69 \\
6 \\
0\end{array}$ & $\begin{array}{l}7 \\
0 \\
0\end{array}$ \\
\hline 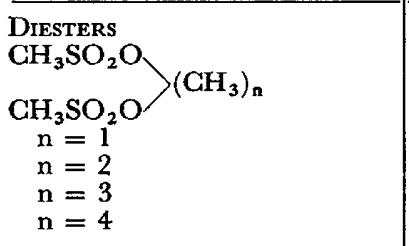 & $\begin{array}{r}15 \\
100 \\
50 \\
10\end{array}$ & $\begin{array}{l}26 \\
16 \\
28 \\
15\end{array}$ & $\begin{array}{l}73 \\
41 \\
86 \\
87\end{array}$ & $\begin{array}{l}51 \\
30 \\
45 \\
60\end{array}$ \\
\hline $\begin{array}{l}\text { ControLs } \\
\text { Dimethyl sulphoxide } \\
(0.4 \mathrm{ml} \text { DMSO }+0.6 \mathrm{ml} \text { saline }) \\
\text { Arachis oil }\end{array}$ & $\begin{array}{c}(m l / k g \text { i.p. }) \\
1 \\
1\end{array}$ & $\begin{array}{l}9 \\
9\end{array}$ & $\begin{array}{r}44 \\
0\end{array}$ & $\begin{array}{r}34 \\
0\end{array}$ \\
\hline
\end{tabular}

Drugs were injected into the peritoneal cavity of pregnant rats on the 15 th day of gestation and then dams were allowed to go to term. The monoesters of methane sulphonic acid were administered in normal saline. The diesters $n=1$ to 3 were dissolved in a solution of dimethyl sulphoxide and normal saline, Busulphan $(n=4)$ was suspended in arachis oil. The values recorded are means derived from groups of rats, each group contained at least five animals.

Methyl methanesulphonate caused a slight reduction in weight of ovaries and like ethyl methanesulphonate had no effect on weight of the genital tract.

Isopropyl methanesulphonate, the diesters $\mathrm{n}=1,3,4$ and dimethyl sulphoxide caused a substantial decrease in ovarian and accessory sex organ weight.

\section{DISGUSSION}

The response of the rat foetal ovary to busulphan $(\mathrm{n}=4 ; 10 \mathrm{mg} / \mathrm{kg})$ depends on age at the time of treatment (Hemsworth \& Jackson, 1963b). When the compound was administered by the intraperitoneal route to dams on the 5 th or 7 th day of pregnancy there was no discernible effect on foetal germ cells; later a 
destructive action became more powerful, coincident with the arrival of primordial germ cells in the developing ovary. The foetal ovary differs from the foetal testis in presenting a phase insensitive to busulphan late in pregnancy, presumably associated with the onset of meiotic prophase in developing oocytes. Thus the action of busulphan in the foetal ovary appears to be confined to oogonia. Likewise, the branched chain monoester isopropyl methanesulphonate $(50 \mathrm{mg} / \mathrm{kg})$ and the diesters $\mathrm{n}=1$ and 3 caused sterility due to interference with oogonia (Table 1). Methyl and ethyl monoesters were less destructive. Offspring aged 4 months were fertile, although by the time they were a year old most had become sterile. It is likely that treatment reduced the number of oocytes in these offspring and that surviving germ cells were gradually eliminated by atresia and ovulation. In young male counterparts, methyl and ethyl methanesulphonate reduced the number of spermatocytes, although by Day 15 post partum re-population was occurring in their testes (Hemsworth, 1966). These observations support the view that these compounds reduced the number of germ cells in young female offspring.

From a comparison of Tables 1 and 2 there appears to be a clear correlation between intensity of antifertility action and degree of reduction in ovarian and genital tract weight. This effect is particularly marked in the case of the monoester isopropyl methanesulphonate and the diesters $n=1,3,4$. The reduction in ovarian weight cannot be explained by loss of germ cell mass alone and is due largely to absence of Graafian follicles and corpora lutea.

Monoesters and the diester $\mathbf{n}=1$ caused sterility of female offspring whilst male litter mates were fertile (Hemsworth, 1968), suggesting that oogonia are more susceptible than gonocytes to the destructive action of these compounds. This result is probably due to differences in the post-natal development of the gonad. Proliferation of surviving germ cells can occur in the male (Hemsworth \& Jackson, 1963a) whereas the rat ovary has a limited number of oocytes at birth and apparently no means for their replenishment, although congenital reduction in the number of oocytes may invoke a mechanism tending to the conservation of survivors (Beaumont, 1962). Oogonia and gonocytes were susceptible to the cytocidal action of the diesters $n=3$ and 4 ; hence it is possible that either compound in lower dosage may have an antifertility action in female offspring which is compatible with male fertility.

In adult male rats dimethylene dimethanesulphonate $(\mathrm{n}=2 ; 100 \mathrm{mg} / \mathrm{kg})$ causes sterility referable to interference with post-meiotic germ cells (Jackson, 1965). The present studies emphasize the selective nature of this action, for in near-lethal dosage the compound did not appear to interfere with the developing ovary nor affect fertility. Furthermore, this ester $(n=2)$ did not produce teratogenic changes (Hemsworth \& Jackson, 1965).

Action of isopropyl methanesulphonate, like the diesters $n=1,3$ and 4, in the foetal ovary appeared to be confined to oogonia. When dams were treated on the 20th day of pregnancy, by which time oocytes are normally present in the foetus, offspring were fertile. Quantitative analysis of their germ cell population and prolonged fertility testing would establish whether treatment affected the number of oocytes or reproductive capacity. Due to the embryotoxicity of methyl and ethyl methanesulphonate near to term (Hemsworth, 1968) it was 
not feasible to assess whether oocytes would be damaged by these compounds.

No clear evidence of a relationship between structure and antifertility activity due to interference with the foetal ovary emerged from the study of the biological effects of this homologous series of compounds.

\section{ACKNOWLEDGMENTS}

I wish to thank Dr Harold Jackson for supplying the compounds used in this study.

\section{REFERENCES}

Beaumont, H. M. (1962) Effect of irradiation during foetal life on the subsequent structure and secretory activity of the gonads. F. Endocr. 24, 325.

Bollag, W. (1954) Cytostatica in der Schwangershaft. Schweiz. med. Wschr. 84, 393.

Gatton, D. A. G. \& Trle, M. (1956) The use of myleran and similar agents in chronic leukemia. Adv. Cancer Res. 4, 73.

HEMSWORTH, B. N. (1966) Biological effects of alkane sulphonic esters on proliferating cell systems associated with reproductive processes. $\mathrm{Ph} . \mathrm{D}$. thesis.

Hemsworth, B. N. (1968) Embryopathies in the rat due to alkane sulphonates. F. Reprod. Fert. 17, 325.

Hemsworth, B. N. \& JAckson, H. (1963a) Effect of busulphan on the developing gonad of the male rat. F. Reprod. Fert. 5, 187.

Hemsworth, B. N. \& JAGKson, H. (1963b) Effect of busulphan on the developing ovary in the rat. 7. Reprod. Fert. 6, 229.

Hemsworth, B. N. \& JACKson, H. (1965) Embryopathies induced by cytotoxic substances. In: Biological Council Symposium on Embryopathic Action of Drugs, p. 116. Eds. J. M. Robson, F. Sullivan and R. L. Smith. Churchill, London.

JAckson, H. (1965) Problems in the chemical control of male fertility. In: Biological Council Symposium on Agents Affecting Fertility, p. 62. Eds. C. R. Austin and J. S. Perry. Churchill, London.

Jackson, H., Fox, B. W. \& CRAIG, A. W. (1961) Antifertility substances and their assessment in the male rodent. F. Reprod. Fert. 2, 447. 